УДК 398.22:392.28(497.7)(049.3)

https://doi.org/10.55302/MF2180169f

Лени Фрчкоска

\title{
ПОЛИТИКА, ИДЕОЛОГИИ, УЖИВАЊЕ И ДЕВИЈАНТНИ СУБЈЕКТИВИТЕТИ ДЕМНАТ ОД ГРОБОТ
}

\begin{abstract}
Апстракт: Текстот претставува анализа на: политичката, социјалната и идеолошката заднина на легендите и на верувањата за вампирите, собрани на територијата на Република Македонија, низ концептот на технологијата на создавањето на телото на чудовиштето претставен во студијата Skin Shows: Gothic Horror and the Technology of Monsters од Џудит Халберстам, а исто така и низ некои концепти од филозофијата на Жак Лакан, прикажани преку анализите на современата култура од страна на Славој Жижек.
\end{abstract}

Клучни зборови: вампир, политика, идеологија, педагогија, субјективизација.

Следниот текст е фокусиран на анализа на легендите и верувањата за вампирите, собрани на територијата на Република Македонија.

Иако постои голема сличност меѓу карактерот на вампирот во земјите од Западен Балкан (особено вампирот во: српските, хрватските, македонските и бугарските легенди), нема да потпаднам на искушението за едноставна споредба. Наместо тоа, ќе ја фокусирам мојата анализа на: политичката, социјалната и идеолошката заднина на овие приказни, преку концептот на технологијата на создавање на телото на чудовиштето и монструозното. Овој концепт е темелно претставен во студијата Skin Shows: Gothic Horror and the Technology of Monsters од Џудит Халберстам, а исто така и низ некои концепти од филозофијата на Жак Лакан, прикажани преку анализите на современата култура од страна на Славој Жижек.

Иако Халберстам е фокусирана на западната готика, ликот на вампирот и контекстот во кој тој (многу поретко таа) се појавува во македонскиот фолклор е многу сличен со контекстот на појавата на западниот готски. Халберстам тврди дека „готската фантастика е технологија на субјективизација, таква што произведува девијантни субјективитети наспроти кои се препознаваат нормалните, здравите и чистите“ (Halberstam 2006: 2).

Може да се каже дека вампирот е манифестација на човековиот длабок, освестен, но и несвесен страв од смртта, од непознатото, од загубата на сакана личност, но „како што покажаа критичари како Мишел Фуко, Жил Делез и Феликс Гатари, самото несвесно и сите негови механизми се производи на историска и културна продукција“ (Halberstam 2006: 8).

Освен несвесниот страв од смртта, фигурата на вампирот, во легендите, може да се анализира преку теоријата на Алан Дандес, според кого фолклорот „обезбедува социјално санкционирана рамка за изразување на критични проблеми што предизвикуваат анксиозност“ (Dundes 1980: 9). Овој став ќе стане клучна точка во анализите на легендите за вампирите во врска со темите на инцестот или на злоупотребата на религијата од страна на свештениците. 
Некој може да се претвори во вампир ако не е погребан правилно, односно ако погребните ритуали не се следат правилно. Постои кратка легенда за жена, која починала и се вратила како вампир, лута затоа што не била погребана правилно. Нејзиниот сопруг бил скржав и не платил за свештеник на нејзиниот погреб. Ритуалот по погребот не бил правилно извршен и таа се вратила да бара правда, не дозволувајќи нејзиниот сопруг да живее во мир.

Словенечкиот филозоф Славој Жижек во својата книга Looking Awry: An Introduction to Jacques Lacan through Popular Culture ce обидува да одговори на многу едноставно прашање што се појавува во речиси секоја митологија, секој фолклор и секоја современа култура поврзана со темата за враќање на мртвите.

Ајде тогаш да поставиме наивно и елементарно прашање: зошто мртвите се враќаaт? Одговорот што го нуди Лакан е ист како оној што се наоѓa во популарната култура: бидејќи не биле правилно закопани, односно затоа што нешто не било во ред со ритуалите, кои го следат погребот. Враќањето на мртвите е знак на нарушување на симболниот ${ }^{1}$ ритуал, во процесот на симболизација; мртвите се враќаат како наплатувачи на неплатен долг кон симболната традиција. Ова е основната лекција што ја извлекува Лакан од Антигона и Хамлет. Заплетите на двете драми вклучуваат несоодветни погребни ритуали, а „живите мртви“ - Антигона и духот на таткото на Хамлет - се враќаат за да ги расчистат сметките кон симболниот поредок. Враќањето на живите мртви, значи, материјализира одреден симболен долг, кој опстојува и по физичко исчезнување. Вообичаено е да се каже дека симболизацијата како таква е еднаква на симболно убиство: кога зборуваме за нешто, ја суспендираме, ја ставаме во заграда, неговата реалност. Токму поради оваа причина погребниот ритуал ја претставува симболизацијата во најчиста форма: преку неа, мртвите се впишани во текстот на симболниот поредок, тие се уверени дека, и покрај нивната смрт, „ќе продолжат да живеат“ во сеќавањата на заедницата. „Враќањето на живите мртви“ е, од друга страна, обратно од правилниот погребен ритуал. Додека едното подразбира одредено помирување, прифаќање на загубата, враќањето на мртвите означува дека тие не можат да го најдат своето соодветно место во текстот на традицијата.

(Žižek 1991: 22).

Сопругата, бидејќи не била погребана правилно, се вратила да го подмири неплатениот симболен долг. Бидејќи не е впишана во текстот на симболниот поредок, таа се враќа да го подмири долгот, но и да одржи лекција (педагогија за важноста да се следи традицијата и, следствено, ризикот од игнорирањето на ритуалите).

\footnotetext{
${ }^{1}$ Терминот симболен/на/но (а не литературно прецизните, но во случајов несоодветни симболичен или симболички) се користи во контекст на идејата за Симболниот поредок, една од клучните идеи во теоријата на Жак Лакан.
} 
Значи, оваа конкретна приказна споделува многу традиционалистичка порака.

Главниот концепт од читањето на Халберстам за чудовиштето и за монструозното ќе излезе на виделина преку анализите на легендите и на нивните карактеристични елементи.

Вампирите можат да се поделат во пет различни групи (Спировска и Вражиновски 1988: 19):

1. Вампир-сопруг, односно сексуален партнер - Овој вампир, кој не успеал да создаде потомство пред својата смрт, се враќа од гробот за да има односи со својата сопруга. Таа обично забременува, но потоа го предава својот „сопруг“ и тој умира. Детето од оваа врска, обично син, расте како човек со ретки способности, способен да ги гледа и да ги убива вампирите. Кога вампирот лежи покрај својата сопруга, тој е студен и тоа ја прави свесна дека тој всушност е вампир.

2. Вампир-домаќин - Овој тип е познат како добар вампир. Обично тоа е вампир, кој бил татко во многу сиромашно семејство и кој по смртта се враќа да му помага на семејството.

3. Вампир-штетник - Ова е најпознатиот тип. Повеќето легенди се за овој тип вампир. Контактот со него обично завршува со смрт или со болест. Луѓето што го гледаат, понекогаш умираат од страв. Убива луѓе, убива животни. Ги пали нивните куќи...

4. Вампир-касап - Појавата на ваков вампир има корени во верувањето дека пие крв. Овој вид не е опасен за луѓето. Тој ги убива животните откако ќе ја испие целата нивна крв. Го откриваат откако ќе го боцнат со игла, по што се претвора во баричка крв.

5. Вампир-животно - Може да се претвори во животно, често во куче.

Она што е очигледно, главно од првиот, но и од вториот тип вампир, е дека легендите за вампирот, како што е споменато погоре, всушност се педагогија за следење на традицијата.

Во патријархалното општество на Западен Балкан (иако легендите беа собрани во 20 век, верувањата произлегуваат од многу порано) потомството за мажот е обврска, симбол на машкост, услов да се биде „вистински маж“, а исто така и главна цел во бракот. Вампирот што се враќа за да создаде потомство, слично како и жената, која не била погребана правилно, се враќа да подмири симболен долг. Под притисокот на неправилно впишан во текстот на симболната традиција, се враќа да го исплати својот долг кон традицијата и сликата за мажот и за семејството. Дури и по смртта не може да почива во мир.

Повторно, легендата ја одржува лекцијата дека традицијата мора да се почитува и дека секоја непослушност доаѓа со висока цена. Слична е судбината на вториот тип вампир, кој, иако бил татко, не можел да се грижи и да го обезбеди своето семејство. И тоа е безусловниот апел (unconditional demand; Žižek 1991: 22) на патријархалната традиција од светот на живите што одекнува и не дозволува мир ниту по смртта.

Третиот тип вампир, штетникот, се појавува во различни контексти што можат да се протолкуваат низ различни општествени и политички 
перспективи. Интересно е што жените и мажите што стануваат вампири се однесуваат слично. Не дозволуваат живите (обично членовите на најблиското семејство) да живеат во мир. Ја убиваат нивната стока, ги палат нивните залихи со храна, ги плашат итн. Но, она што е особено интересно е дека силната ограниченост од полот на кој му припаѓаат, повеќе не постои. Патријархалните општества ги ограничува поединците во силнодефинирани родови улоги. Некои вампири се враќаат во светот на живите однесувајќи се родово-флуидно. Истите тие вампири, на крајот на легендата, секогаш се убиени или протерани од селото.

Идејата за полот на овие вампири, прикажана преку ликот на проколнат паразит што мора да биде убиен, е аргумент во корист на тврдењето на Халберстам за Дракула, според кое, тој, во форма на вампир, отелотворува „перверзна сексуалност“ и дека „сведувањето на сексуалноста на идентитет и верзија на идентитетот (перверзија - одвраќање од идентитетот) во готските романи ја консолидира нормалната сексуалност дефинирајќ́ ја како различност од нејзините монструозни манифестации“ (Halberstam 2006: 17).

Постојат многу примери во кои вампирите стануваат олицетворение на - и лекција против - таканаречената перверзна сексуалност или „карактеризирање на монструозноста како претстава на психолошко нарушување“" (Halberstam 2006: 18).

Има приказна за вампир-штетник што сексуално напаѓa друг маж со дрвен стап. Подоцна е протеран од селото.

Според Халберстам, готското истовремено предизвикува страв и желба - страв и желба за другиот, страв и желба за можна латентна перверзија што демне во самиот читател/ка. Но, стравот и желбата во истото тело создаваат дисциплинирачки ефект. Готиката им предизвикува возбуда на читателите, кои читаат за таканаречени перверзни активности додека истовремено ги идентификуваат „погрешните“ сексуалности како состојба на другост и како суштинска особина на туѓи тела. Чудовиштето, се разбира, ја означува границата меѓу неговата перверзна сексуалност и претпоставено дисциплинираната сексуалност на читателот. Исто така, означувачите на „нормалната“ сексуалност одржуваат еден вид хегемонска моќ, притоа останувајќи невидливи (Halberstam 2006: 13).

Значи, гореспоменатиот сексуален напад од еден маж (чудовиште, вампир) врз друг може да се протолкува како лекција против хомосексуалноста, претставувајќи ја како монструозна перверзија. Вампирот, мртов и од различен домен, ја држи „перверзната“ сексуалност настрана, далеку од дисциплинираниот реципиент на приказната, кој добива лекција да ја следи традицијата, да создаде потомство и да биде способен да се грижи за него. Отфрлањето или убивањето на вампирот, предизвикува страв од последиците на самата желба, дури и пред да се помисли на нејзина реализација. 


\section{Инцестуозниот вампир и неговата ќерка}

Еден од ретките и особено интересни примери е приказната за таткото, кој починал и се вратил да ја „испие“ својата ќерка, непосредно пред нејзината венчавка.

Таткото и ќерката живееле заедно. Мајката починала пред многу години. Таткото договорил брак за својата ќерка, но непосредно пред бракот, точно пред младоженецот да дојде да ја земе ќерката, таткото се разболел и починал. Од тага за неговата ќерка се претворил во вампир и се вратил да ја „испие“, односно, неколку дена по смртта затропал на вратата и таа го пуштила да влезе.

Оваа легенда има структура на бајка што не е често случај со легендите за вампирите. Потсетува на постарата верзија на Пепелашка во која таткото одлучува дека е предодреден да се ожени со својата ќерка. Слични бајки се дел и од колекцијата на Рејчел Хариет Баск.

Легендата е приказна за инцестуозен татко, кој се враќа како вампир „од тага за својата ќерка“, како што се цитира во приказната, всушност да ја убие и да не дозволи да се случи бракот. Целосно да ја консумира својата керка.

Уште еднаш, преку чудовиштето, главниот предмет на приказната е сексуалната перверзија - инцест - и ја консолидира нормалната сексуалност дефинирајќи ја како различна од нејзината монструозна манифестација. Овде, преку инцестуозниот татко, отелотворен во вампир, „чудовиштето се дефинира и како различно од замислената заедница и како суштество што не ни може да се замисли како заедница“" (Halberstam 2006: 15).

Има еден интересен дел од приказната, дијалогот меѓу таткото-вампир и неговата ќерка, кој потсетува на дијалогот меѓу Црвенкапа и волкот во спалната на бабата.

- Татко - велит - зашто ти се очите такви крвоји?

- Е, Велико, ќерко. Моји очи - твоју крв пију.

Таја се плаши сега.

- А, бре, татко - велит - тато, зошто толкаји нокти. Немаше ти толкаји нокти?

- Велико ќерко. Моји нокти - твоје грло ждрапшају.

(Спировска и Вражиновски 1988: 72).

Подоцна ќерката го убедува да ја испрати во подрумот да донесе вино. Тој ѝ врзува јаже околу половината, за да не избега. Сепак, таа го врзува јажето за коза и бега. Тој, луто, ги убива сите животни во фармата, но потоа кукуригаат петлите и тој умира.

Тука телото на чудовиштето ја покажува својата способност „во едно тело да собере што е можно повеќе застрашувачки карактеристики“ (Halberstam 2006: 21). Неговата надворешност е полна со симболи, кои предизвикуваат страв: се појавува како нечовек, отворено сака да ја силува и да ја убие сопствената ќерка, се појавува елементот на канибализам (,пиење“ на ќерката), целиот речник (во дијалогот татко - ќерка) и неговиот физички изглед (црвените очи и долги нокти), тоа што коле осумдесет кози и овци... 
Предметот на оваа конкретна легенда е инцестот, нешто што било (и останува) табу. Така, фолклорот овде ја исполнува улогата на педагогија, која ограничува и забранува, но претставува и „социјално санкционирана рамка за изразување на критични проблеми што предизвикуваат анксиозност“ (Dundes 1980: 9).

Вампирот, пред својата смрт, бил дел од групата, некој што бил член на таа заедница, но се вратил од гробот за да бара правда или да ја потсети заедницата на потиснатите чувства и пориви што сѐ уште постојат под слоевите правила, норми и традиции. Бидејќи претходно бил дел од заедницата што сега ја прогонува, често личи на неговото човечко јас. Тој ,jа закотвува абјекцијата во рамки на телото, туѓо тело кое задржува одредена сличност и затоа создава збунетост за границата меѓу себе и другите“ (Halberstam 2006: 18). Значи, не може да се предвиди кој ги потиснувал забранетите чувства и нагони, и кој може да се врати како вампир.

Оваа несигурност поврзана со фигурата на вампирот се споменува и во студијата на Умберто Еко За г̄pgoӣo. Еко пишува дека вампирот „станува вознемирувачки не толку многу кога се појавува како лилјак-суштество од чии песјаци капе крв затоа што во тој случај сѐ што успева да направи е да нѐ уплаши, туку тогаш кога ни се појавува сомнеж - несигурност - дека некој е вампир“ (Есо 1980: 322). Еко, исто така, пишува дека вампиризмот е еден многу популарен пример за необичното, алудирајќк на она што Сигмунд Фројд го нарекува зловесно ${ }^{2}$ (un-canny) и го дефинира како нешто што „несомнено му припаѓa на сето она што е страшно - на сето она што предизвикува страв и притаен ужас“ (Freud 2003: 1) и дека „тоа е класата на застрашувачко што води назад кон нешто што ни е одамна познато, некогаш многу познато“ (Freud 2003: 2).

Овој страв и вознемиреност пред неизвесноста веројатно и довел до ликот на убиецот на вампирот, кој, во македонскиот фолклор, е син на вампирот. Самиот вампир, всушност, го засадил семето на своето уништување и направил син, кој е единствениот способен да го препознае и да го убие. Анксиозноста пред неизвесноста е причината за појавата на ликот на ваквиот син, кој може да го види таткото (и оние како него). И, исто така, рамнотежата во структурата на бајките бара херој што ќе триумфира над чудовиштето. Керката и нејзината лукавост и нејзината интелигенција триумфираат над перверзните нагони на нејзиниот татко, додека вампирџијата е единствениот што може да го препознае вампирот кога е во форма на животно, сенка или едноставно ветер.

\footnotetext{
2 Терминот зловесно го користи Огнен Чемерски како превод на иn-сипnу на Сигмунд Фројд во студијата Како gа се бияе ге еј на Дејвид М. Халперин (види во М. Дејвид Халперин. 2019. Како gа се бияе г̄ej. Скопје: Темплум.)
} 


\section{Свештеникот што се претворил во вампир}

Постои кратка легенда за свештеник, кој се претворил во вампир. Не постои причина зад оваа трансформација. Она што е многу интересно во оваа приказна е тоа што поврзува два многу различни домени, светото и проколнатото. Тоа покажува дека границата меѓу двете може да биде многу порозна. Она што е уште поважно е клучното толкување на приказната што суптилно укажува на лицемерието на членовите на црквата и злоупотребата на таа позиција. Од друга страна, може да биде, уште еднаш, пример за изразување проблеми и табуа што предизвикуваат критична вознемиреност во овој случај злоупотреба на моќта на членовите на црквата.

Ова е исто така уште еден доказ за ефектот на сомнежот, бидејќи не е лесно да се претпостави дека фигурата на авторитет, која често (погрешно) ги користи аргументите за Бог, може да се претвори во нешто толку блиску до демонското.

Халберстам забележува:

Создавањето ефект на страв во книжевните текстови (за разлика од филмскиот текст) произлегува од вртоглавиот вишок на значење. Готиката, на некој начин, реферира на орнаментален ексцес (помислете на готска архитектура, гаргојлите и лудите спирали), реторичка екстраваганција која, едноставно, произведува премногу. Во рамките на готските романи, во текстот се вградени повеќе толкувања и искуството на хоророт доаѓ и од сознанието дека и самото значење е во бунт.

(Halberstam 2006: 2).

Елементите на орнаментален ексцес се очигледни во физичкиот изглед на вампирот. Како што споменавме порано, инцестуозниот вампир-татко имал очи толку црвени за да ја испие крвта на својата ќерка и долги нокти за да ѝ го пресече вратот. Постојат и други описи, кои се примери за оваа гротескна реторичка екстраваганција. На пример, откако вампирот ќе се боцне со игла, тој се претвора во крваво желе или понекогаш во крваво желе големо како измет од вол.

Следниот пример потсетува на некои аспекти на физичкиот изглед на грофот Дракула на Брам Стокер, вампирот во литературата, кој влече корени од романскиот, но и пошироко, од словенскиот фолклор:

И тамо сетне со пушка го отепале и со варена вода го натуриле и тогај се истурила крвта од него. И така тој... Ама ко шо е, мршата стое, очите црвени, ноктите црвени, нокти токае пораснале црвени алски, очите алски црвени, лицето угу крв с'то црвено, мршата цела црвена.

(Спировска и Вражиновски 1988: 41).

Ова е пример за употреба на премногу придавки и вербални повторувања за физички опис на лик во многу кратка легенда - фолклорен текст, обично лишен од какви било описи, освен потребните. Овие детали, во 
приказната, која најчесто е кратка и структурирана многу едноставно, укажуваат дека раскажувачите ги користеле како начин да се фокусираат на подробностите за монструозноста на вампирот, и на сите други аспекти што сугерираат на неговата абнормалност, паразитизам и нечовечност.

Тука е важно да се спомене еден посебен атрибут на македонскиот вампир, а тоа е верувањето дека причина за трансформација во вампир е длабокиот копнеж за дома што се јавува додека живеете далеку (Спировска и Вражиновски 1988). Зад оваа одлика се крие политичка и социјална порака за сиромаштијата и притисокот од принудното заминување на печалба, тема што е дел од животот на генерациите од Македонија и како таква стана важна тема во различни форми на локален фолклор.

На самиот крај од анализите ќе го споменам толкувањето на Славој Жижек за чудовиштето како лик сместен целосно надвор од идеологијата и од политиката. Надвор од каква било интерпретација.

Анализите што се фокусираат на 'идеолошкото значење' на чудовиштата го занемаруваат фактот дека, пред да означат нешто, пред да послужат како сад за значење, чудовиштата го отелотворуваат уживањето како граница на толкување, односно незначењейо како такво.

(Žižek 1991: 64).

Тука Жижек го става чудовиштето во сферата на чистото уживање, надвор од границата на означувачите и толкувањата што се дел од симболниот поредок. Чистото уживање што доаѓ од другата страна (или од гробот) на сите општествени, политички и идеолошки начела на симболниот поредок.

\section{ЗАКЛУЧОК}

Вампирските легенди во македонскиот фолклор, очигледно, се кратки лекции за важноста на силните традиционалнонаметнати норми и одговорност за машкоста и за семејството. На подлабоко ниво, тие истовремено тематизираат културнопотиснати табуа за кои е премногу срамно да се зборува отворено, но исто така се сметаат за опасни и неприродни и клучни за контрола и за санкционирање, како што се флуидноста на родот, хомосексуалноста и инцестот.

Во исто време, тие дури нудат простор, простор и време што постојат само во однос на приказната (прераскажување, слушање, размислување за приказната). Тоа е време за скришноотворен простор кога, на дискретен начин, се живее, евентуално, потисната емоција што може да ја ослободи личноста од силата на поривот, да се трансформира поривот и да се одржи лекција за многу строгата казна, која би била последица на вистинското реализирање на поривот и на желбата во реалниот живот.

Кога сите овие значења и толкувања се калемат врз крвавите очи, канџи и песјаци на чудовиштното тело, заедницата ја означува разликата меѓу себеси и другото, изопаченото и нормалното, познатото и туѓото. 


\section{ЛИТЕРАТУРА}

\section{Кирилични изданија}

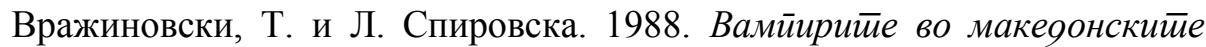
верувања и йреяанија. Скопје: Институт за фолклор „Марко Цепенков““

\section{Латинични изданија}

Dundes, A. 1980. Interpreting folklore. Bloomington: Indiana University Press.

Eco, U. 2007. On ugliness. London: Harvil Secker.

Freud, S. 2003. The Uncanny. New York: Penguin Books.

Halberstam, J. 2006. Skin Shows: Gothic Horror and the Technology of Monsters. Duke University Press.

Kristeva, J. and S. L. Roudiez. 1982. Powers of horror: an essay on abjection. Columbia University Press.

Žižek, S. 1991. Looking Awry: an introduction to Jacques Lacan through popular culture. MIT Press.

\section{Сајтографија}

Žižek, S. 1991. "Grimaces of the real, or when the phallus appears", October, vol. 58, The MIT PRESS, 45-68. JSTOR https://doi.org/10.2307/778797 [Пристапено на 31.05.2021].

Leni Frčkoska

\section{POLITICS, IDEOLOGY, GRATIFICATION AND LURKING OF DEVIANT SPECIES}

\section{Summary}

The following text is an analysis of the political, social and ideological background of the legends and beliefs about vampires, collected on the territory of the Republic of Macedonia through the concept of technology (historically and culturally conditioned) of producing the monsters presented in the study Skin Shows: Gothic Horror and the Technology of Monsters by Judith Halberstam, and also through concepts from Jacques Lacan's philosophy, presented through the analysis of contemporary culture by Slavoj Žižek. 